\title{
New record of Cheyletiella parasitivorax (Mégnin, 1878) (Trombidiformes: Cheyletidae) from Brazil with an illustrated key to species for the genus
}

\author{
Novo registro de Cheyletiella parasitivorax (Mégnin, 1878) (Trombidiformes: \\ Cheyletidae) para o Brasil, com uma chave ilustrada das espécies deste gênero
}

\author{
Darci Moraes Barros-Battesti 1,2* ${ }^{2}$, Ricardo Bassini-Silva², Fernando de Castro Jacinavicius ${ }^{3}$, \\ Marcos Rogério André', Ronald Ochoa ${ }^{4}$, Raphael Vieira Ramos ${ }^{5}$, Silmara Marques Allegretti ${ }^{5}$
' Departamento de Patologia Veterinária, Faculdade de Ciências Agrárias e Veterinárias, Universidade Estadual Paulista - UNESP, Jaboticabal, SP, Brasil
${ }^{2}$ Departamento de Medicina Veterinária Preventiva e Saúde Animal, Faculdade de Medicina Veterinária e Zootecnia - FMVZ, Universidade de São Paulo - USP, São Paulo, SP, Brasil
${ }^{3}$ Laboratório Especial de Coleções Zoológicas, Instituto Butantan, São Paulo, SP, Brasil
${ }^{4}$ Systematic Entomology Laboratory, United States Department of Agriculture, Agricultural Research Service, Beltsville, MD, USA \\ ${ }^{5}$ Departamento de Biologia Animal, Instituto de Biologia, Universidade Estadual de Campinas - UNICAMP, Campinas, SP, Brasil
}

\begin{abstract}
How to cite: Barros-Battesti DM, Bassini-Silva R, Jacinavicius FC, André MR, Ochoa R, Ramos RV, et al. New record of Cheyletiella parasitivorax (Mégnin, 1878) (Trombidiformes: Cheyletidae) from Brazil with an illustrated key to species for the genus. Braz J Vet Parasito/ 2020; 29(2): e018819. https://doi.org/10.1590/S1984-29612020016
\end{abstract}

\begin{abstract}
The cheyletid mites that parasitize mammals have been neglected for a long time in Brazil, although they can be common on pets and cause injury to their hosts. Recently, Cheyletiella parasitivorax was found parasitizing a rabbit in Brazil which represents a new host and distribution record for the mite species. An illustrated dichotomous key for the identification of the species in this genus and data from the literature are provided.
\end{abstract}

Keywords: Cheyletiellosis, São Paulo State, morphology, identification key.

\begin{abstract}
Resumo
Os ácaros da família Cheyletidae que parasitam mamíferos são negligenciados há muito tempo no Brasil, embora eles sejam comuns em animais domésticos. Considerando as dificuldades morfológicas para diagnosticar as espécies dessa família que infestam mamíferos, este estudo refere-se a uma nova ocorrência de Cheyletiella parasitivorax incluindo os poucos registros de literatura. Além disso, também está sendo apresentada uma chave dicotômica ilustrada para identificação de espécies desse gênero.
\end{abstract}

Palavras-chave: Cheyletiellosis, Estado de São Paulo, morfologia, chave de identificação.

\section{Introduction}

The superfamily Cheyletoidea consists of the following five families of mites: Cheyletidae Leach 1815; Demodicidae Nicolet 1855; Harpirhynchidae Dubinin 1957 (including Ophioptinae); Psorergatidae Dubinin 1957 and Syringophilidae Lavoipierre 1953. Except for Harpirhynchidae and Syringophilidae, which are mainly associated to reptiles and birds, the other families usually parasitize mammals, and some are also associated with arthropods.

Cheyletidae is represented by approximately 400 species worldwide, distributed in 74 genera. The genera are divided into two groups; one of them consists of free-living mites and predators of arthropods, including other mites, and comprises more than half of the described species; the second group consists of species associated with different classes of vertebrates, including humans (Gerson et al., 1999; Walter et al., 2009). 
In a phylogenetic reconstruction of the Cheyletidae published by Bochkov \& Fain (2001), the authors proposed 15 tribes in the family, which were maintained by Bochkov (2009). Bochkov \& Fain (2001) included four genera in the Cheyletiellini tribe: Cheyletiella Canestrini 1886, Eucheyletiella Volgin 1969, Nihelia Domrow \& Baker 1960 and Criokeron Volgin 1966, which are associated with mammals; and three genera in the Ornithocheyletiini tribe: Bakericheyla Volgin 1966; Neocheyletiella Baker 1949 and Ornithocheyletia Volgin 1964, which are associated with birds.

Fain \& Bochkov (2001) synonymized the genus Bicheyletiella Fain 1972 with Cheyletiella, transferring Bicheyletiella romerolagi Fain 1972 to Cheyletiella. In addition, they synonymized two other species of Cheyletiella; as a result, there are currently five valid species: Cheyletiella blakei Smiley 1970; Cheyletiella parasitivorax (Mégnin 1878); Cheyletiella romerolagi (Fain 1972); Cheyletiella strandtmanni Smiley 1970; and Cheyletiella yasguri Smiley 1965. Usually, C. yasguri is associated with dogs (Fain et al., 1982), C. blakei with cats (Pfeiffer, 1979) and C. parasitivorax with rabbits (Bronswijk \& Kreek, 1976). These nonburrowing mites can cause severe dermatitis on their hosts including people who are in contact with infected pets (Keh et al., 1987; Fain \& Bochkov, 2001).

The study of the cheyletid mites parasitic on vertebrates has been neglected in Brazil and other countries in South America, although they can cause injury to humans and other hosts. Since there is still little information about this family in Brazil, we are providing a new locality record of $C$. parasitivorax and including information on the genus gathered from the literature. In addition, an illustrated dichotomous key to separate the species of this genus is provided, based on the key published by Fain \& Bochkov (2001).

\section{Materials and Methods}

Specimens of $C$. parasitivorax were collected on an infested rabbit, Oryctolagus cuniculus L. in the Jundiai municipality (23 11' 11" S 46 53' 4" W), São Paulo state, Brazil. The collected material was preserved and stored in $100 \%$ alcohol. Later, part of the material was slide-mounted in Hoyer's medium for identification. The slide preparations were in accordance with Walter \& Krantz (2009), and a part of them was deposited in the collection of the Pathology Department of UNESP, Jaboticabal, named as "Museu Didático de Parasitologia do Departamento de Patologia Veterinária da UNESP de Jaboticabal". The specimens were identified to genus according to Gerson et al. (1999) and to species using the key published by Fain \& Bochkov (2001) along with the examination of type material and their original descriptions (Smiley, 1965, 1970; Fain, 1972).

Besides the specimens of $C$. parasitivorax collected in the present study, we examined material of this species deposited at Acari Collection of the Instituto Butantan, São Paulo (IBSP), and from the collection of the National Museum of Natural History, [formerly United States National Museum -USNM], which is housed at the Systematic Entomology Laboratory (BARC-USDA-ARS) in Beltsville, Maryland. Types and material of other species of Cheyletiella deposited at the collection of the USNM were also examined by one of us (RB-S) in order to prepare the illustrations. The material of C. parasitivorax from Jundiaí was photographed using an Olympus microscope, DP 73, and CellSens Imaging software (Olympus), in the Immunoparasitology Laboratory, Department of Veterinary Pathology, Universidade Estadual Paulista (UNESP Jaboticabal). Type species and material were also photographed using a Zeiss Axioplan 2 imaging with DIC and Phase Contrast microscope in the USNM. Images were prepared with Adobe Photoshop v. 13.0 and Inkscape V.2. The distribution map was prepared using DIVA-GIS.

\section{Results and Discussion}

Cheyletiellinae is characterized by the presence of a feather-like empodia on tarsi of the legs I-IV, tarsi without claws and solenidia absent on tibia of the leg I. Cheyletiella has sickle-like setae and lacks comb-like setae on the palptarsus; has an edentate palpal claw; peritremes with more than three broad links; idiosoma oval; legs II and III separated; a single wide propodosomal shield present bearing 4-5 pairs of setae; dorsal setae slender, nude or barbed; humerals similar to the other dorsal setae $(/ 1)$; solenidion $(\varphi)$ present on genu of the leg I and absent on tibia of the leg I; all tarsi without claws and with feather-like empodia (Gerson et al., 1999).

Listed below are the types and material examined of Cheyletiella species, used to prepare the identification key modified from that of Fain \& Bochkov (2001).

Cheyletiella romerolagi (Fain, 1972) was not examined, due the fact there are no types or material deposited at the USNM collection. The species was described from specimens found on a volcano rabbit, Romerolagus diazi (Ferrari-Pére), in New York, USA and also has been recorded in Mexico on the same host (Gerson et al., 1999). 
According to Fain (1972), the chaetotaxy of C. romerolagi is similar to that of other species of Cheyletiella. Fain \& Bochkov (2001) described the male of C. romerolagi.

Cheyletiella parasitivorax (Mégnin 1878) (Figure 1)
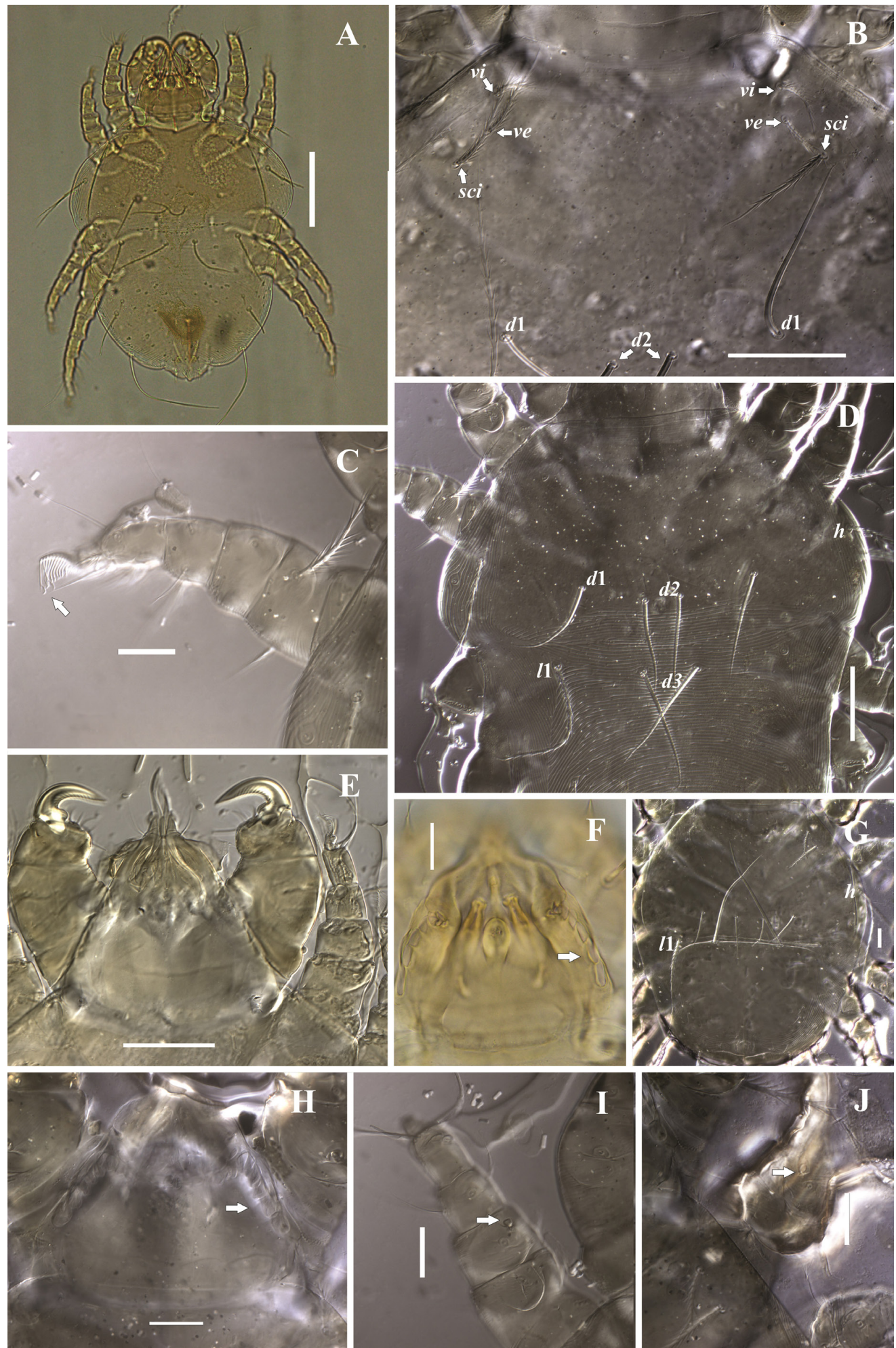

Figure 1. Morphological details of Cheyletiella parasitivorax. (A) Female, dorsal view; (B) Female, anterior propodosomal shield; (C) Female, empodium of tarsus II; (D) Female, posterior propodosomal shield; (E) Female, gnathosoma and palpi; (F) Female, peritremal links; (G) Male, dorsal view; (H) Male, peritremal links; (I) Female, globose solenidion; (J) Male, oblong solenidion. Abbreviations: $d 1-d 3$, dorsal setae; $h$, line h setae; /1, lateral setae; sci, scutal internal setae; ve, vertical external setae; vi, vertical internal setae. Scales: A $100 \mu \mathrm{m} ; \mathrm{B}, \mathrm{D}, \mathrm{E} 50 \mu \mathrm{m} ; \mathrm{C}, \mathrm{F}, \mathrm{G}, \mathrm{H}, \mathrm{I}, \mathrm{J} 20 \mu \mathrm{m}$. 
Material examined: five specimens (present study), four female and one male collected on Oryctolagus cuniculus in Jundiaí, SP; three females collected on the ears of $O$. cuniculus in the Instituto Butantan, São Paulo municipality, SP (IBSP 250 and 251); and two specimens (a male and female) collected on a marsh rabbit, Sylvilagus palustris, in Jacksonville City, Florida, USA.

Distribution: Worldwide. In Brazil, C. parasitivorax was only known to occur in the São Paulo state - São Paulo city (Amaral, 1971) and Garça city (Alvim et al., 2005), and in Rio de Janeiro state - Seropédica city (Fernandes et al., 2013). The new occurrence of this species on a rabbit from Jundiai city (present study) is the third record of the species in the state of São Paulo. Amaral (1971) did not mention São Paulo city, however, we have confirmed the locality by consulting the information with the person who made the drawing of the male presented in the paper. The distribution of this species is shown in Figure 2.

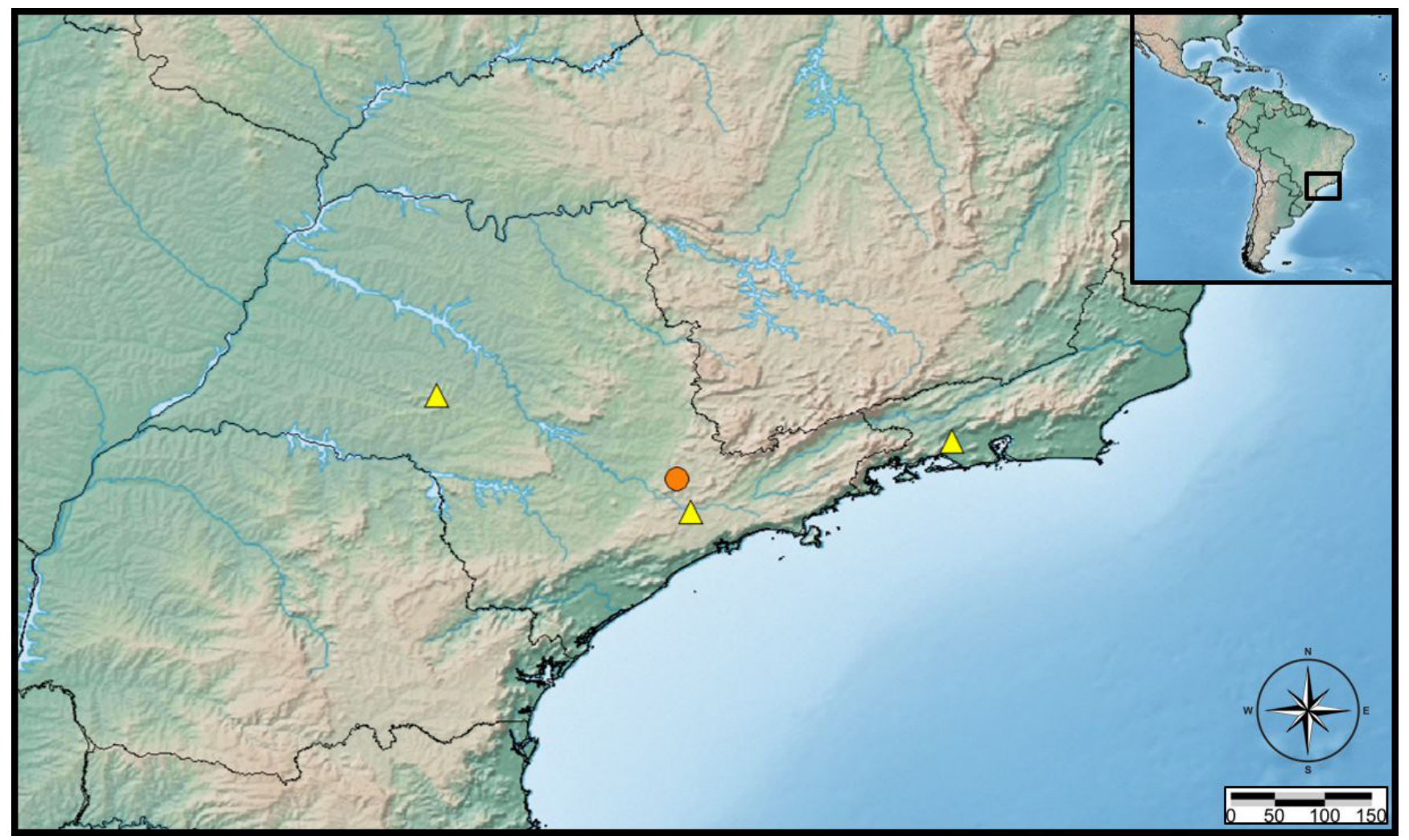

Figure 2. Geographical distribution of Cheyletiella parasitivorax in Brazil. The yellow triangles represent a literature record, and orange dot is the new record.

\section{Cheyletiella blakei Smiley 1970 (Figure 3)}

Type examined: Holotype (USNM 3346), male, ex. cat (Felis catus), Ithaca City, Tompkins County, New York, USA. Four paratypes, two males and two females, same data as for holotype.

Distribution: This species usually parasitizes cats and occurs in Canada, (Paradis, 1998), USA, Belgium, Italy, Turkey, Norway, Netherlands, Germany (Bronswijk \& Kreek, 1976), Greece (Bowman, 2014; Lefkaditis et al., 2015). It has also been recorded in Santiago, Chile on dogs, in Denmark on dogs and their owners, and in the USA (Bronswijk \& Kreek, 1976).

Cheyletiella strandtmanni Smiley 1970 (Figure 4)

Type examined: Holotype (USNM 3345), female, ex. Lepus sp., Taiwan, 17 Apr. 1952.

Distribution: Taiwan (SMILEY, 1970). Male unknown.

Cheyletiella yasguri Smiley 1965 (Figure 5)

Type examined: Holotype (USNM 2956), female, ex. a schnauzer dog (Canis lupus familiaris), Mamaroneck City, Westchester County, New York, USA. Paratypes, two males and one female, ex. dog (Canis lupus familiaris), Cornell University, Ithaca City, Tompkins County, New York, USA. 

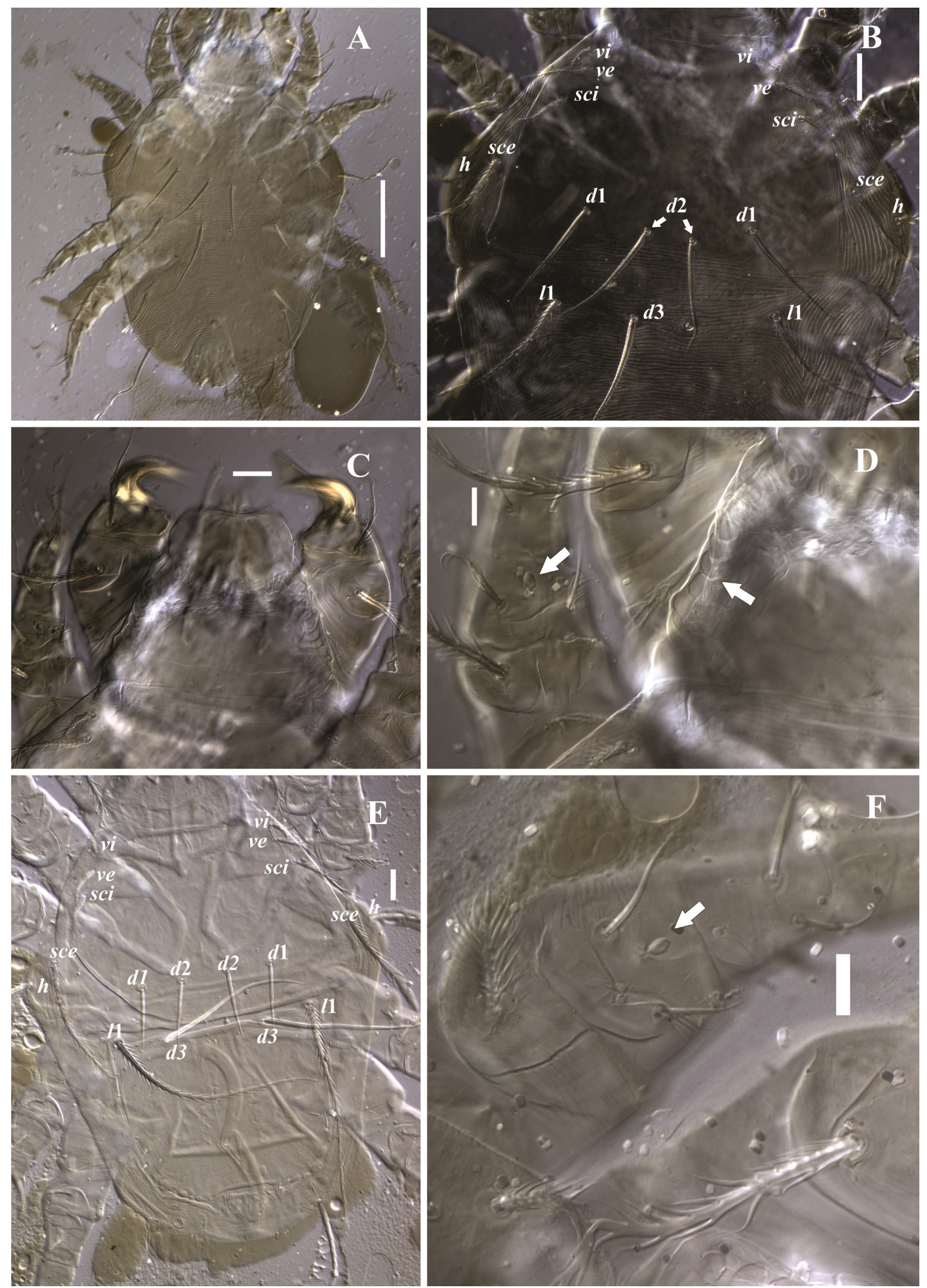

Figure 3. Morphological details of Cheyletiella blakei (Paratype USNM 3346). (A) Female, dorsal view; (B) Female, anterior propodosomal shield; (C) Female, gnathosoma and palpi; (D) Female, peritremal links and conical solenidion on genu I; (E) Male, dorsal view; (F) Male, conical solenidion on genu I. Abbreviations: $d 1$ - $d 3$, dorsal setae; $h$, line h setae; 11 , lateral setae; sce, scutal

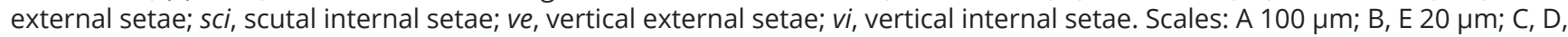
$\mathrm{F} 10 \mu \mathrm{m}$. 

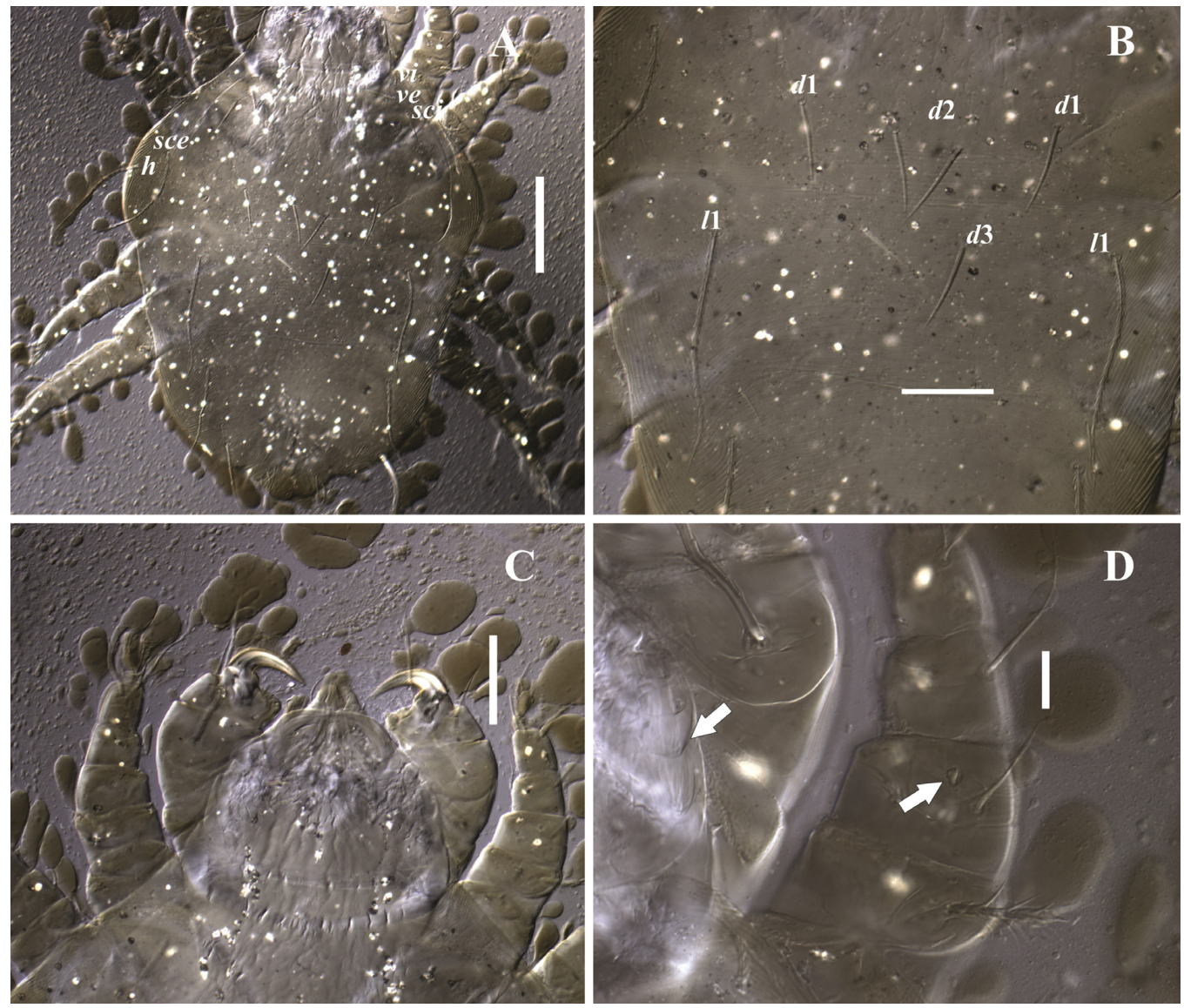

Figure 4. Morphological details of Cheyletiella strandtmanni (Holotype female USNM 3345). (A) Dorsal view; (B) Anterior propodosomal shield; (C) Gnathosoma and palpi; (D) large peritremal links and Y-shaped solenidion on genu I. Abbreviations: $d 1-d 3$, dorsal setae; $h$, line h setae; /1, lateral setae; sci, scutal internal setae; ve, vertical external setae; vi, vertical internal setae. Scales: A $100 \mu \mathrm{m} ; \mathrm{B}, \mathrm{C} 50 \mu \mathrm{m}$; D $20 \mu \mathrm{m}$.

\section{Distribution: Worldwide.}

Dichotomous key of Cheyletiella species (females and males), based on the key published by Fain \& Bochkov (2001), and the original descriptions of Smiley $(1965 ; 1970)$ and Fain (1972)

1. Hysterosomal shield of female three times wider than long, without setae and setae $d 2$ slightly longer than 11; setae vi (internal vertical seta) located off the propodosomal shield; male hysterosomal shield as wide as long with setae vi located on the propodosomal shield; parasite of volcano rabbit (Romerolagus diazi

C. romerolagi

Hysterosomal shield present in males and located posterior to the first pair of lateral setae (/1); absent in the females, except $C$. yasguri which has two small and rounded hysterosomal shields. 2

2. Hysterosoma of female with two small and rounded shields located laterally and posterior to the first pair of lateral setae (/1); solenidion on genu of the leg I heart-shaped in both females and males; male with a single, longer than wide dorsal hysterosomal shield; parasite of dogs

C. yasguri

Hysterosomal shields absent in females, present in males . .3

3. Males and females with the setae $d 2$ much shorter (three times) than the setae (/1); solenidion on genu I Y-shaped; parasite of rabbits (Lepus sp.

C. strandtmani

Males and females with the setae $d 2$ subequal in length to the setae (/1) or slightly shorter 4

4. Solenidion on genu of the leg I, globular in females and oblong in males; one pair of $h$ setae and $v i$ on the propodosomal shield in males and females; males; parasite prefers rabbits

C. parasitivorax

- Solenidion on genu of the leg I conical in males and females; one pair of $h$ and $v i$ off the propodosomal shield in males and females; parasite of cats

C. blakei 

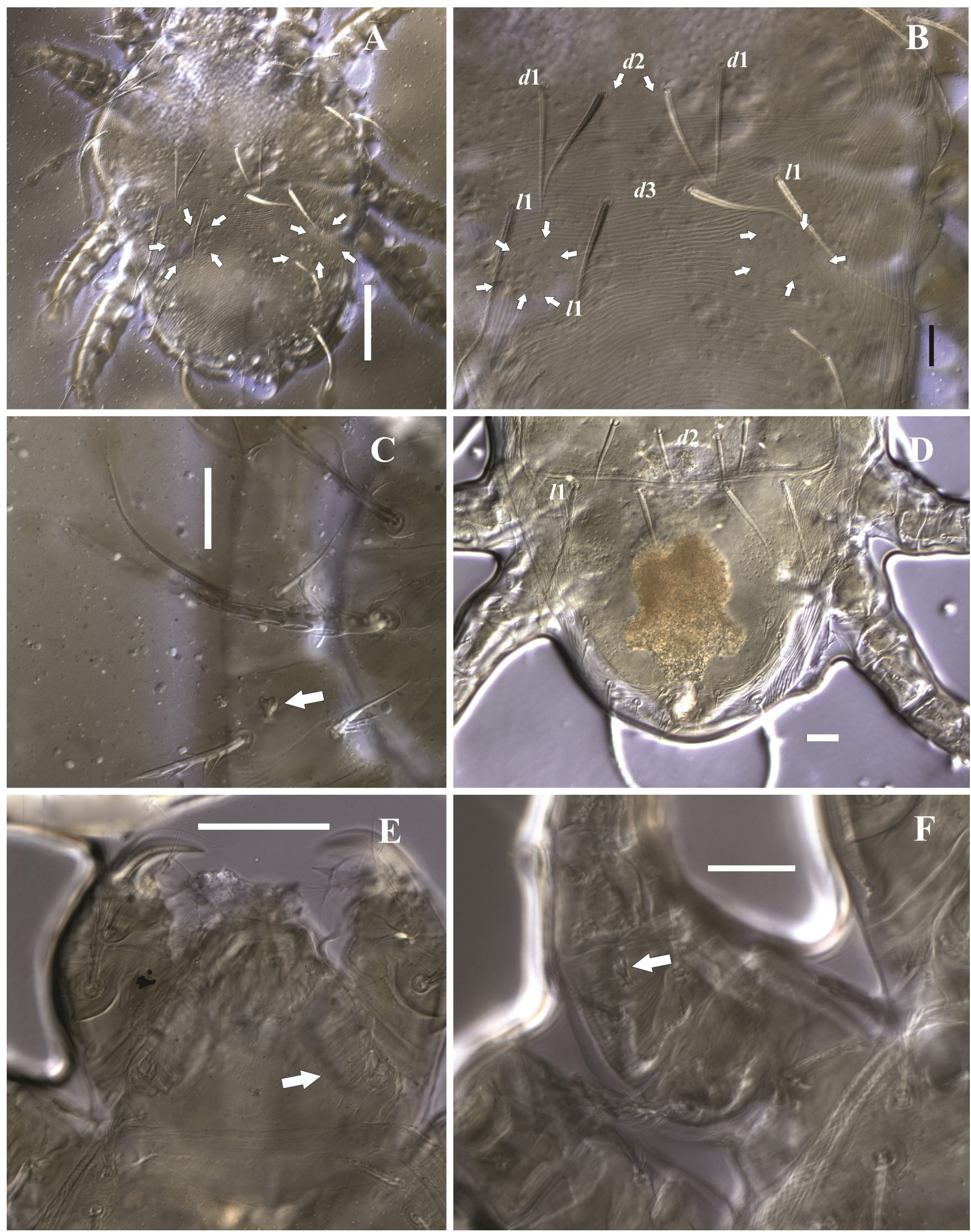

Figure 5. Morphological details of Cheyletiella yasguri (Holotype USNM 2956 and paratype). (A) Female, dorsal view, the setae indicate a pair of small rounded hysterosomal shields; (B) Hysterosomal shields; (C) Female, heart-shaped solenidion on genu I; (D) Male, hysterosomal shield; (E) Male, large peritremal links; (F) Male, heart-shaped solenidion on genu I. Abbreviations: d1-d3, dorsal setae; /1, lateral setae. Scales: A $100 \mu \mathrm{m} ; \mathrm{B}, \mathrm{E} 50 \mu \mathrm{m} ; \mathrm{C}, \mathrm{D}, \mathrm{F} 20 \mu \mathrm{m}$. 


\section{Clinical case}

A four-year-old male rabbit was observed with dandruff on its back and itching due to the parasitism of C. parasitivorax. The clinical signs started twenty days before the patient was taken to the clinic (Figure 6). The rabbit had no contact with other animals according to its owners. Skin scraping and acetate tape impression test were made. The owners had moved to another place about two months before and probably the adaptation stress caused the loss of balance between the parasite and its host. The animal was treated with a single administration of selamectin pour-on (Zoetis Revolution ${ }^{\circledR} 6 \%$ ) and daily brushings of the fur. No dandruff and itching were observed after three weeks of the treatment.

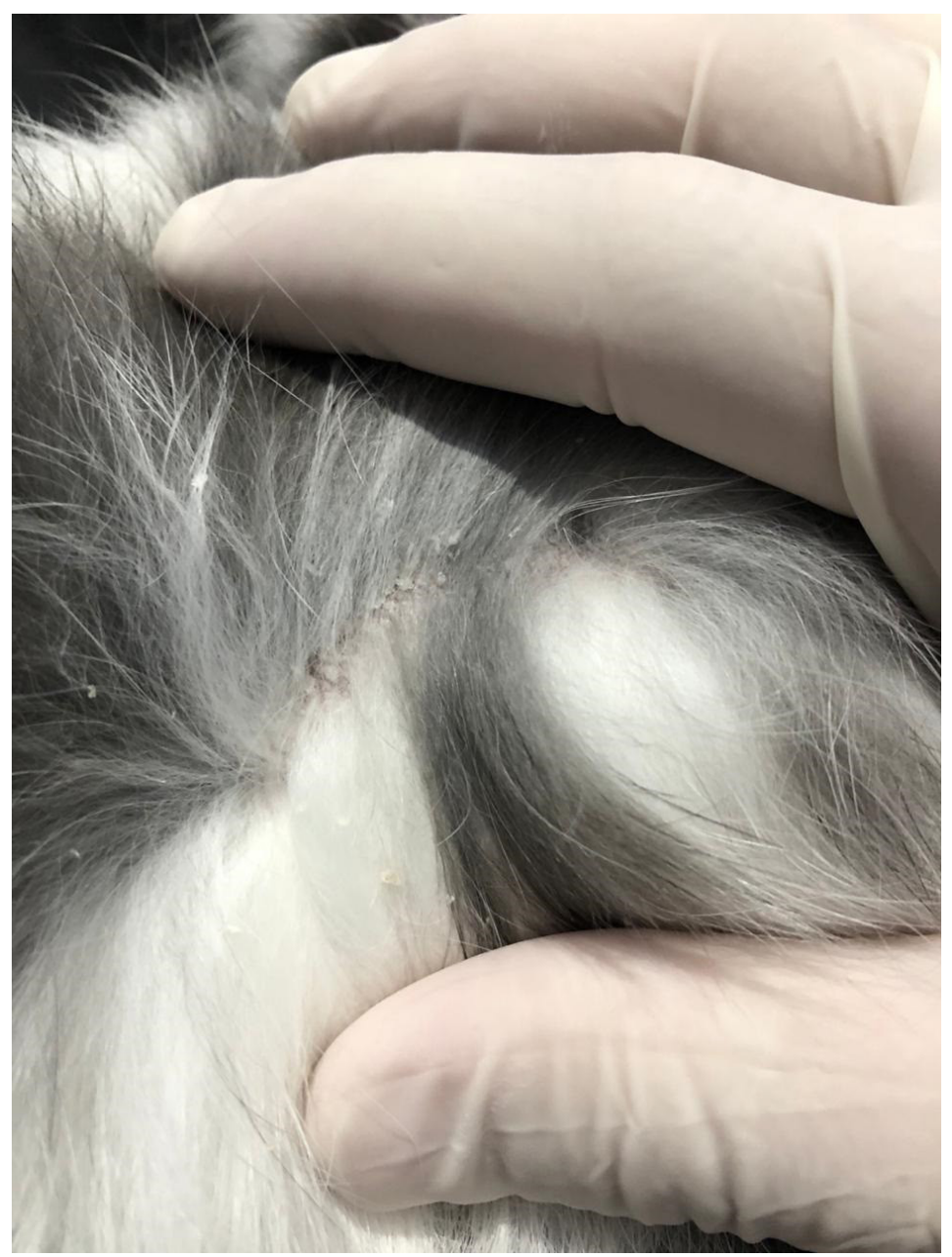

Figure 6. Dandruff flakes in the dorsal region of the rabbit infested by C. parasitivorax.

\section{Acknowledgements}

To the veterinarians Gustavo and Adriano Bauer, owners of the clinical center where the animal was attended; and to Matheus Alves Moreira and Danaê Avanze Cação for bringing the mites to confirm the identification. To Dr. Gregory Evans, APHIS-PPQ, USDA for the revision of the manuscript and his recommendations. The Smithsonian Natural History Museum and National Agricultural Library (NAL-USDA), SEL-USDA for support and assistance with specimens and references. This work was supported by the Conselho Nacional de Desenvolvimento Científico e Tecnológico (CNPq no. 454907/2014-1 and 440639/2015-8 to DMB-B, 377976/2014-8 to FCJ), Fundação de Amparo à Pesquisa do Estado de São Paulo (FAPESP no. 2010/51875-9 to DMB-B and 2017/01416-7 and 2018/24667-8 to RB-S). This study was financed in part by the Coordenação de Aperfeiçoamento de Pessoal de Nível Superior - Brasil (CAPES) - Finance Code 001. Mention of trade names or commercial products in this publication is solely for the purpose of providing specific information and does not imply recommendation or endorsement by the USDA; USDA is an equal opportunity provider and employer. 


\section{References}

Alvim NC, Bonadia GO, Pena SB, Bissoli EAG. Queiletielose em cão. Rev Cient Eletrônica Med Vet 2005; 5: 1-3.

Amaral V. Ocorrência do ácaro Cheyletiella parasitivorax (Mégnin, 1878), (Ararina, Cheyletidae) em coelho doméstico (Oryctolagus cuniculus), no Brasil. Biologico 1971; 37: 106-107.

Bochkov AV, Fain A. Phylogeny and system of the Cheyletidae (Acari: Prostigmata) with special reference to their host-parasite associations. Bull Inst R Sci Nat Belg 2001; 71: 5-36.

Bochkov AV. A review of mites of the parvorder Eleutherengona (Acariformes: Prostigmata) - permanent parasites of mammals. Acarina: KMK Scientific Press; 2009.

Bowman D. Arthropods. In: Bowman D. Georgis'parasitology for veterinarians. 10th ed. Missouri: Elsevier Saunders; 2014. p. 67-79.

Bronswijk JEMH, Kreek EJ. Cheyletiella (Acari: Cheyletiellidae) of dog, cat and domesticated rabbit, a review. J Med Entomol 1976; 13(3): 315-327. http://dx.doi.org/10.1093/jmedent/13.3.315. PMid:1011235.

Fain A, Bochkov AV. A review of some genera of cheyletid mites (Acari: Prostigmata) with descriptions of new species. Acarina (Mosc) 2001; 9(1): 47-95.

Fain A, Scheepers L, De Groot W. Long-lasting pruriginous dermatitis in a woman caused by an acarian dog parasite Cheyletiella yasguri Smiley. Rev Med Liege 1982; 37(18): 623-625. PMid:6183724.

Fain A. Notes sur les acariens des famill1es Cheyletidae et Harpyrhynchidae producteurs de gale chez les oiseaux ou les mammiferes. Acta Zool Pathol Antverp 1972; 56: 37-60. PMid:4668512.

Fernandes Jl, Verocai GG, Ribeiro FA, Melo RMPS, Correia TR, Coumendouros K, et al. Efficacy of the d-phenothrin/pyriproxyfen association against mites in naturally co-infested rabbits. Pesq Vet Bras 2013; 33(5): 597-600. http://dx.doi.org/10.1590/S0100736X2013000500008.

Gerson U, Fain A, Smiley RL. Further observations on the Cheyletidae (Acari), with a key to the genera of the Cheyletinae and a list of all known species in the family. Bull Inst R Sci Nat Belg 1999; 69: 35-86.

Keh B, Lane RS, Shachter SP. Cheyletiella blakei, an ectoparasite of cats, as cause of cryptic arthropod infestations affecting humans. West J Med 1987; 146(2): 192-194. PMid:3825118.

Lefkaditis MA, Sossidou AV, Panorias AH, Koukeri SE, Pastiu Al, Athanasiou LV. Urban stray cats infested by ectoparasites with zoonotic potential in Greece. Parasitol Res 2015; 114(10): 3931-3934. http://dx.doi.org/10.1007/s00436-015-4688-4. PMid:26319525.

Paradis M. Mite dermatitis caused by Cheyletiella blakei. J Am Acad Dermatol 1998; 38(6): 1014-1015. http://dx.doi.org/10.1016/ S0190-9622(98)70182-3. PMid:9632026.

Pfeiffer H. Cheyletiella-befall der Hauskatze. Z Parasitenkd 1979; 59(1): 95-106. http://dx.doi.org/10.1007/BF00927850.

Smiley RL. A review of the family Cheyletiellidae (Acarina). Ann Entomol Soc Am 1970; 63(4): 1056-1078. http://dx.doi.org/10.1093/ aesa/63.4.1056.

Smiley RL. Two new species of the genus Cheyletiella. Proc Entomol Soc Wash 1965; 67(2): 75-79.

Walter DE, Krantz GW. Collecting, rearing, and preparing specimens. In: Krantz GW, Walter DE. A manual of Acarology. Lubbock: Texas Tech University Press; 2009. p. 83-96.

Walter DE, Lindquist EE, Smith IM, Cook DR, Krantz GW. Order Trombidiformes. In: Krantz GW, Walter DE. A manual of Acarology. Lubbock: Texas Tech University Press; 2009. p. 233-420. 